\title{
PRINSIP-PRINSIP KEPEMIMPINAN TRANSFORMATIF BERDASARKAN KITAB NEHEMIA DAN IMPLIKASINYA BAGI KEPEMIMPINAN ROHANI MASA KINI
}

\author{
Sail Lola \\ Nelly Petronella Tuhumury \\ sttjaffray@yahoo.com
}

\section{PENDAHULUAN}

\section{Latar Belakang Masalah}

Bangsa Indonesia kini mencapai usia 64 tahun, dalam usia tersebut tentu saja ada banyak kerinduan dan harapan bagi bangsa ini. Pertanyaan penting bagi para pemimpin ialah apa yang telah dicapai dalam kurun waktu tersebut dan sejauh mana para pemimpin telah membawa bangsa ini kepada cita-cita bangsa ini seperti yang tercantum dalam pembukaan Undangundang Dasar 1945 dalam alinea terakhir: "Negara yang pemerintahannya melindungi segenap bangsa Indonesia dan seluruh tumpah darah Indonesia dan untuk memajukan kesejahteraan umum, dan mencerdaskan kehidupan bangsa, dan ikut melaksanakan ketertiban dunia yang berdasarkan kemerdekaan, perdamaian abadi dan keadian soasial"

Kalau melihat potret kehidupan masyarakat saat ini, masih jauh dari cita-cita di atas. Sampai detik ini sejumlah masalah masih mengidap di tubuh bangsa ini. Di bidang Politik, hukum dan keamanan, bangsa kita adalah raksasa rapuh. Sementara budaya koruptif begitu akut dan sistemik ada di seluruh struktur urusan publik yang merugikan rakyat dan berbagai penyimpangan-penyimpangan di bidang hukum yang seyogyanya adalah lembaga untuk menegakkan keadilan tetapi justru hukum di Indonesia sangat rapuh dan bisa diperjualbelikan. Di sektor Kesra, sejumlah borok bangsa masih belum hilang: Angka kemiskinan tinggi. Pendidikan dan kesehatan mahal. Anak-anak busung lapar belum hilang dari angka statistik. Ini adalah wujud minimnya rasa empati negara terhadap kesengsaraan rakyatnya. Di bidang ekuin. Rakyat tidak berdaulat atas nasib ekonomi sendiri. Akibatnya, kita krisis energi. Antre minyak menjadi pemandangan sehari-hari. Antre bensin, dan Pemadaman listrik.

Kenapa itu semua terjadi? Banyak faktor yang menjadi penyebabnya. Tapi, ada satu faktor mendasar yang menjadikan itu semua terjadi, yaitu kegagalan para elite dalam memimpin bangsa ini. Sejatinya seorang pemimpin adalah orang yang secara berani mengambil alih masalah orang lain menjadi tanggung jawab dirinya. Celakanya, beberapa dekade kepemimpinan bangsa ini justru diemban bukan oleh seorang problem solver. Jika pun ada, masih malas berpikir. Tidak kreatif dalam mencari solusi. Setidaknya masih tambal sulam. Akibatnya, tidak ada satu masalah bangsa pun yang terselesaikan secara tuntas.

Tak heran jika akhirnya masalah-masalah yang membelit bangsa ini jadi bertumpuk dan tidak pernah diselesaikan. Sebab, kepemimpinan yang ada hanya sibuk membangun benteng kekuasaan dengan permainan citra. Kemal Stamboel menjelaskan,

"Semua masalah bangsa diselesaikan dengan retorika, iklan di media massa, atau setidaknya dengan kata "akan" lewat statement di forum kenegaraan. Dengan kata "akan" itu seolah-olah masalah telah terselesaikan. Padahal tidak. Persis seperti seorang ABG yang mendempul wajahnya dengan bedak tebal guna menutupi bopeng bekas jerawat. Wajahnya terlihat mulus memang. Tapi, bopeng di wajahnya masih tetap ada. ${ }^{1}$ 
Karena itu, bangsa ini memerlukan pemimpin baru. Pemimpin yang menjadi problem solver. Pemimpin seperti ini tentu lahir dari generasi baru. Bukan dari generasi lawas pewaris kepemimpinan pola lama. Bukan juga berasal dari individu yang terlibat dan menyangga kepemimpinan masa lalu.

Perubahan baru yang signifikan, baru akan terjadi jika terjadi perubahan kepemimpinan yang cukup radikal. Bangsa ini membutuhkan pemimpin baru. Pemimpin yang menjadi antitesis karakteristik kepemimpinan gaya lama. Tapi, tentu saja kepemimpinan baru itu tidak berpola pikir nihilis. Pasti ada sisi-sisi positif yang dihasilkan dari kerja kepemimpinan masa lalu. Halhal positif itu tentu saja batu pijakan yang bagus untuk memulai step baru bagi perjalan bangsa ini ke depan.

Proses kelahiran kepemimpinan baru saat ini sangat memungkinkan. Syarat-syarat yang ada, baik berupa kondisi sosial, ekonomi, dan politik sudah lengkap. Tinggal satu faktor penting yang belum ada yaitu munculnya aktor yang berinisiatif menjadi penggerak perubahan. Perlu orang yang berani, jujur dengan cita-cita perjuangan, memiliki komitmen dan keteguhan terhadap ideologi dan cita-cita perjuangan, serta sabar dalam berjuang. Aktor perubah berkarakter seperti itulah yang dibutuhkan sebagai pemimpin di hari ini.

Krisis kepemimpinan tidak hanya terjadi dalam pengelolaan Negara, tetapi juga di dalam kalangan gereja. Mengapa hal ini terjadi? Bukankah ada banyak yang menyatakan diri sebagai pemimpin? Lalu mengapa masih banyak masalah yang timbul dan hampir melumpuhkan organisasi yang ada?

Kepemimpinan merupakan motor penggerak roda suatu organisasi. Organisasi dapat berfungsi dengan baik jika digerakkan oleh pemimpin yang baik pula. Lingkungan gereja merupakan salah satu lokasi penerapan kepemimpinan. Para pemimpin rohani mempunyai tugas dan tanggung jawab yang cukup berat tetapi mulia adanya karena Tuhanlah yang empunya pelayanan tersebut yang memberikan kuasa dan kemampuan kepada mereka dan para pemimpin hanya sebagai alat yang menjalankan tugas pelayanan tersebut.

Peran pemimpin amat menentukan arah perubahan yang sedang dituju. Oleh karena itu pemimpin harus mampu menangkap peluang perubahan dengan menghimpun seluruh potensi yang ada, sehingga perubahan itu benar-benar terjadi.

Dalam usaha membuat sebuah perubahan, tentu saja setiap pemimpin mengalami berbagai macam tantangan dan persoalan, seperti adanya perubahan yang begitu cepat dalam masyarakat modern, berkembangnya kepemimpinan sekuler, meningkatnya kualitas anggota masyarakat, dan meningkatnya kemajemukan dalam masyarakat, termasuk dalam masyarakat gereja. Perkembangan Ilmu Pengetahuan dan teknologi tentu saja membawa dampak atau pengaruh bagi kehidupan manusia. Selain itu, yang menjadi kendala seorang pemimpin adalah adanya keinginan dari anggota jemaat yang ingin mempertahankan tradisi lama (Status quo) sehingga terkadang gereja masih tertutup dan sulit untuk membuat sebuah perubahan.

Untuk itu, dalam menghadapi perubahan yang semakin deras dan berbagai tantangan di atas, semakin dibutuhkan kualitas pemimpin yang mampu melihat esensi peranannya, mengambil sikap yang tepat, menyusun strategi yang jitu, serta mengajak seluruh warganya mengikuti arah yang terbentang di depannya. Untuk itu dibutuhkan sosok seorang pemimpin yang tidak hanya mampu melewati tantangan yang ada tetapi juga dapat menghasilkan suatu perubahan, serta memberi manfaat maksimal bagi kepentingan bersama. ${ }^{2}$ 
Pentingnya menghadirkan sosok pemimpin rohani yang mampu membawa perubahan bagi masa depan sudah sering didengungkan. Jika berangkat dari realita yang terjadi, setiap elemen dalam masyarakat dan gereja memerlukan pemimpin yang benar-benar ingin menunjukkan dirinya sebagai pemimpin sungguhan. Namun yang terjadi malah sebaliknya, kebanyakan orang masih berkata dirinya pemimpin, namun kelakuannya masih jauh dari tingkah laku serta citra seorang pemimpin. Hal ini masih nampak dalam lingkungan gereja. Demikian Sonny Eli Zaluchu yang dikutip oleh Dr. Daniel Ronda, Th.M. menjelaskan bahwa "kelemahan kepemimpinan gembala ditandai dengan sejumlah aktivitas yang cenderung memaksakan kehendak, ....., visi yang lemah, doa yang kurang serta sikap mencerminkan kekunaon. Dan hal yang paling utama adalah gembala yang tidak mau berubah dan selalu tertutup menerima masukan karena menganggap diri benar." ${ }^{3}$ Di samping itu, banyak pemimpin Kristen tidak berjalan dengan visi dari Tuhan. Pelayanan dan organisasinya dibangun atas dasar cita-cita dan pemikiran akal budi manusia. ${ }^{4}$

Seyogyanya pemimpin haruslah melaksanankan fungsinya sebagaimana mestinya, dan kembali prinsip-prinsip kepemimpinan yang berdasarkan firman Tuhan sehingga mampu melakukan sebuah perubahan. Namun realita yang ada masih jauh dari apa yang diharapkan.

Bertolak dari latar belakang masalah tersebut di atas, maka penulis menulis karya ilmiah dengan judul: "PRINSIP-PRINSIP KEPEMIMPINAN TRANSFORMATIF BERDASARKAN KITAB NEHEMIA DAN IMPLIKASINYA BAGI KEPEMIMPINAN ROHANI MASA KINI ”

\section{Masalah Pokok}

Dalam penulisan karya ilmiah ini ada dua hal yang menjadi pokok masalah sehubungan dengan pembahasan, yaitu:

Pertama, apa yang dimaksud dengan kepemimpinan transformatif?

Kedua, apa saja prinsip-prinsip kepemimpinan transformatif berdasarkan kitab Nehemia dan implikasinya bagi kepemimpin rohani masa kini?

\section{Tujuan Penulisan}

Penulisan karya ilmiah ini ditulis dengan tujuan :

Pertama, untuk memperoleh pengertian yang benar mengenai kepemimpinan transformatif berdasarkan petunjuk Alkitab.

Kedua, untuk menyelidiki dan mengungkapkan kepemimpinan Nehemia dan bagaimana mengimplikasikannya bagi kepemimpinan rohani masa kini.

Ketiga, sebagai salah satu persyaratan akademik untuk mencapai gelar strata satu (S-1) pada Sekolah Tinggi Theologia Jaffray Makaassar

\section{Manfaat penulisan}

Harapan penulis kiranya karya ilmiah ini akan memberikan manfaat bagi pembaca, khususnya bagi mereka yang berkecimpung dalam bidang kerohanian. Adapun manfaat penulisan karya ilmiah ini yaitu:

Pertama, dengan adanya penulisan ini diharapkan dapat menjadi bahan acuan bagi para pemimpin rohani dalam menjalankan tugas dan tanggung jawab.

Kedua, melalui penulisan karya ilmiah ini penulis banyak menemukan dan mengetahui banyak hal seputar kepemimpinan dan dapat menjadi bahan masukan bagi penulis dalam menjalankan tugas kepemimpinan yang akan diemban kelak. 


\section{Batasan penulisan}

Mengingat terlalu luasnya studi kepemimpinan rohani dalam Alkitab, maka penulis membatasi penulisan karya ilmiah ini secara khusus mengenai prinsip-prinsip kepemimpinan transformatif berdasarkan kitab Nehemia.

\section{Jenis Penelitian}

\section{METODOLOGI PENELITIAN}

Dalam penulisan karya ilmiah ini, penulis menggunakan jenis penelitian kualitatif, dimana tujuan penulisan ini ialah mencari makna prinsip-prinsip kepemimpinan transformatif berdasarkan kitab Nehemia. Penulis memakai pedoman penulisan dari buku Metodelogi Penelitian Filsafat, karya Anton Bakker dan Achmad Zubair.

\section{Sumber dan Materi Penelitian}

Adapun sumber dan materi penelitian yang penulis tempuh dalam penulisan karya ilmiah ini ialah: Pertama, teks dibaca, kemudian dikaji secara biblikal. Kedua, Tafsiran. Ketiga, Literatur kitab Nehemia. Keempat, Literatur kepemimpinan.

\section{Teknik Pengumpulan Data \\ Inventarisasi}

Menurut Anton Bakker dan Achmad Charris Zubair bahwa untuk menginventarisasi sebuah buku maka kita perlu "mempelajari karya tokoh itu sendiri, agar dapat diuraikan isinya dengan setepat dan sejelas mungkin. Mengumpulkan juga bahan yang tersebar dalam kepustakaan mengenai buku itu. Dengan persis meneliti apa yang dikatakan oleh pengarangpengarang mengenai buku itu. Menunjukan dengan tepat kesamaan dan perbedaan dalam uraian mereka. Menjelaskan masalah-masalah yang mereka ajukan, dan usaha pemecahan yang mereka berikan"5. Selain itu penulis perlu menyelidiki konsepsi filosofis (pandangan hidup) yang secara faktual tersembunyi dalam peristiwa, atau keadaan dan situasi, atau fenomena yang merupakan masalah itu." Sehingga dalam penelitian ini, penulis mengumpulkan, menguraikan, dan menjelaskan rinsip-prinsip kepemimpinan transformatif berdasarkan kitab Nehemia. Selain itu mengintegrasikan kesamaan dan perbedaan serta upaya pemecahan atas materi atau pokok bahasan kepemimpinan yang terdapat dalam kepustakaan.

\section{Evaluasi Kritis}

Penulisan karya ilmiah ini, menggunakan metode evaluasi kritis dimana, "Berdasarkan studi langsung mengenai isi buku yang berkaitan dengan kepemimpinan. Penulis perlu membuat perbandingan antara uraian-uraian ahli-ahli mengenai kepemimpinan. Memperlihatkan kekuatan dan kelemahan mereka, ketepatan pemecahan atau kesalahan yang mereka buat. Namun tanpa mengajukan suatu pemecahan sendiri”" Konsepsi itu dikonfrontasi dengan data-data masalah atau situasi yang lengkap saat ini; atau dibandingkan dengan pengalaman orang umum; atau diteliti koherensi intern." 8 


\section{Tekhnik Analisis Data \\ Interpretasi}

Tekhnik Analisis data yang penulis lakukan ialah, "isi buku mengenai kepemimpinan diselami, untuk dengan setepat mungkin menangkap arti dan nuansa uraian yang disajikan oleh tokoh secara khas." ${ }^{9}$ Memberikan opini dan pandangan teoritis dalam menafsirkan atau menginterpretasikan prinsip-prinsip kepemimpinan transformative berdasarkan kitab Nehemia.

\section{Komparasi}

Penulis membuat perbandingan. Adapun perbandingan dibagi menurut beberapa segi: Pertama, Data Lain. Analisis filosofis ini, dan uraian prinsip-prinsip dan dasar-dasar filsafat tersembunyi terus menerus dihubungkan dengan data-data konkret yang telah didepenulisankan. Bahkan juga dapat ditambah data-data dan segi-segi baru, yang belum disebut. Lebih-lebih tambahan itu mungkin perlu untuk dapat memberikan evaluasi tentang filsafat tersembunyi."

Kedua, Situasi Lain. Situasi atau masalah aktual itu dibandingkan dengan situasi-situasi atau masalah-masalah lain, entah real atau fiktif, agar sifatnya yang khas dapat ditentukan sepersis mungkin."

\section{ANALISIS DAN IMPLIKASI KEPEMIMPINAN TRANSFORMATIF BERDASARKAN KITAB NEHEMIA}

\section{Mengenal Kitab Nehemia \\ Latar Belakang Kitab Nehemia}

Sejarah Perjanjian Lama diakhiri dengan kitab Nehemia, ketika orang buangan Yahudi diizinkan kembali ke negeri mereka setelah pembuang di Babel dan Persia.

Paska pembuangan israel dari Babel, Yerusalem pada masa Ezra dan Nehemia tidak banyak berbeda dari Yerusalem yang tidak pernah mendengar perhatian Hagai dan zakaria, yang bernubuat sekitar 60 tahun sebelumnya. Pemberitaan kedua nabi itu ditujukan kepada terjadinya pembaharuan dibidang agama dan sosial. (sekitar 520-512sM; band. Ezra 5:1-2). Kenyataannya, pembangunan kembali Bait Suci yang kedua jauh dari kemegahan bangunan yang dahulu didirikan oleh Salomo (Ezra 3:12). Hagai mendorong mereka untuk segera membangun bait itu di tengah-tengah pengharapan dan penantian mereka akan Mesias. Namun fakta yang tidak bisa dipungkiri ialah kerajaan Persia masih menguasai mereka. Kenyataan pahit yang dihadapi oleh bangsa itu pada zaman Zerubabel adalah sebagai komunitas yang terancam akibat perlawanan musuh-musuh di Yerusalem (band. Ezra 4:1-5; 5:1-7). Ini menyebabkan pudarnya keyakinan Israel terhadap janji Tuhan untuk menjadikan Yerusalem sebagai panji bangsabangsa. Nabi Makeakhi ( sekitar tahun 500-475 sM) juga menegur umat karena melanggar janji iman kepada Tuhan dan menghimbau kepada mereka untuk bertobat. Namun keadaan tersebut belum juga berubah ketika Ezra dan Nehemia tiba di Yerusalem. Kedatangan Nehemia di masyarakat paskah pembuangan diperkirakan tahun kedua puluh dari masa pemerintahan raja Artasasta I (445 sM). ${ }^{12}$

Gambaran umum umat Yahudi di tanah Yehuda kala itu ialah kesalehan bangsa itu sama sekali menyimpang selama abad berganti abad. Kebanyakan di antara raja-raja Yehuda telah membiarkan bahkan menganjurkan penyembahan kepada berhala; hanya sedikit yang tidak berbuat demikian. Mereka telah membuat perjanjian persekutuan dengan bangsa-bangsa lain yang sudah dilarang Allah sebelumnya. Mereka bersikap masa bodoh terhadap perkara-perkara tidak adil yang terjadi dalam masyarakatnya dan yang telah dilarang Hukum Musa. 
Dengan melihat kondisi umat Yahudi yang semakin berada dalam situasi yang terpuruk, maka Imam Ezra membantu Nehemia dalam memajukan kebangunan dan pembaharuan rohani di antara kaum sisa yang kembali. Ini merupakan tugas dan tanggung jawab yang cukup berat bagi Nehemia. Di samping itu, ada tugas yang paling berat ialah yang harus dipikul oleh Nehemia yakni membangun kembali tembok Yerusalem yang telah runtuh akibat serangan musuh.

Kota zaman dulu dibangun dibangun di balik tembok yang tebal dan tinggi. Apabila tembok tersebut runtuh, maka penduduk kota tersebut dalam bahaya. Tembok yang runtuh melambangkan ketidakberdayaan dan keputusasaan penduduk yang ada di balik tembok tersebut. Itulah yang terjadi pada penduduk Yerusalem. Umat Allah berada dalam kondisi yang sangat menyedihkan, hidup dalam eror dan penghinaan. ${ }^{13}$

Nehemia, yang hidup sezaman dengan Ezra, melayani sebagai juru minuman raja Artahsasta (raja Persia) ketika ia menerima kabar orang buangan yang kembali ke Yehuda dari Babel dan Persia sedang mengalami kesulitan dan tembok Yerusalem masih berupa puing. Ketika mendengar hal itu, ia mengerahkan orang-orang sebangsanya untuk membangun kembali seluruh tembok kota dalam 52 hari saja sekalipun terjadi pertentangan gigih. Nehemia menjadi gubernur Yehuda selama 12 tahun; setelah kembali beberapa waktu ke Persia, ia menjadi gubernur Yehuda untuk masa bakti kedua. ${ }^{14}$

\section{Prinsip-prinsip Kepemimpinan Transformatif}

Pada bagian ini penulis akan memaparkan prinsip-prinsip kepemimpinan transformatif berdasarkan kitab Nehemia sebagai berikut:

\section{Memiliki hubungan yang intim dengan Allah}

Kualitas spiritualitas dapat dipahami sebagai kualitas keintiman seseorang dengan Allah yang tercermin dalam penghayatan syukur dan terima kasih atas kebaikan Tuhan. Juga sebagai suatu kerinduan menyerahkan diri dan mengalami kebergantungan pada kuasa dan kehendak Allah. ${ }^{15}$

Kunci utama keberhasilan seorang pemimpin terletak pada sejauh mana hungan dengan Allah. Nehemia adalah pemimpin yang intim dengan Allah. Ada dua hal yang menyebabkan Nehemia begitu dekat dengan Allah, yaitu doa dan taat pada firman Tuhan.

\section{Tekun Berdoa}

Sebelum dan sesudah dia melaksanakan tugasnya ia selalu datang kepada Tuhan melalui doanya. Tuhan menjadi rekan kerjanya. Alkitab mencatat bahwa tiada hentinya dia berbicara kepada Tuhan. Hal ini nampak ketika dia mendengar berita tentang kehancuran tembok Yerusalem, ia datang berlutut dan berdoa kepada Allah (1: 5-11). Dalam melaksanakan tugas dan pelayanannya, ia senantiasa bersandar kepada Allah bukan bersandar pada diri sendiri atau kepada orang lain (4:9). Ketika ia mengalami berbagai macam tantangan termasuk dalam menghadapi musuh-musuhnya (4:4-5)

Secara keseluruhan catatan tentang kehidupannya dipenuhi dengan doa. Bagi Nehemia doa merupakan hal tidak dapat dipisahkan dari kehidupan dan pekerjaan setiap hari. H.L Senduk menjelaskan "seorang anak Tuhan atau hamba Tuhan yang mempunyai kehidupan doa, dengan sendirinya juga melakukan doa pribadinya setiap hari. Sebelum doa pribadinya menjadi sebahagian hidupnya, sama seperti makan, minum, mandi, tidur dan bekerja, maka ia belum memiliki kehidupan doa." 
Penulis melihat ada hal yang sangat menarik dari kehidupan Nehemia. Ketika ia mendengar keadaan tembok Yerusalem telah dihancurkan, ia merasa terpukul secara jasmani sehingga ia menangis, berkabung, berpuasa dan berdoa (1:4). Nehemia berdoa disertai dengan iman yang berpusat pada Allah. Dalam doanya ia berkata, "Ya Tuhan, semesta langit, Allah yang mahabesar dan dahsyat, yang berpegang pada perjanjian dan kasih setia-Nya...."(1:5) Ini merupakan pengagungan Tuhan lewat pengakuannya bahwa Allah itu penguasa alam semesta, kuasa-Nya dahsyat dan setia kepada janji-Nya. Dalam doanya pula berisi pengakuan dosa bangsa. Nehemia mengakui dosanya dan juga dosa-dosa orang lain seakan-akan semua itu dosanya sendiri. Nehemia memiliki rasa turut bertanggung jawab atas dosa bangsanya. Ia mempersamakan dirinya dengan bangsanya dengan segala dosa dan kebutuhan mereka. Ini mencerminkan bahwa Nehemia tidak hanya mempedulikan dirinya sendiri tetapi lebih mengutamakan nasib bangsanya.

Hal di atas menunjukkan doa Nehemia begitu efektif sesuai dengan kebutuhan yang ada. Melalui doanya, Allah melakukan perkara yang luar biasa dalam hidupnya. Pertama Allah memberikan visi yang jelas kepada Nehemia. Kedua, Allah menolong Nehemia ketika ia mulai bekerja dan mulai menggerakkan orang-orang yang dia pimpin. Mereka turut kepada Nehemia dan bekerja dengan penuh semangat. Nehemia sanggup menggerakkan orang-orang yang dia pimpin. J. Oswald Sanders mengutip pernyataan Hudson Taylor bahwa, "kita dapat menggerakkan orang dengan perantaraan Allah, hanya dengan doa". Doa Nehemia memungkinkan dia melakukan perubahan kea rah yang lebih baik dan melalui doa perkara demi perkara berhasil dia selesaikan dengan baik.

\section{Taat Pada Firman Tuhan}

Akar spiritual Nehemia dibangun di atas kebenaran Firman Tuhan. Ia taat dan memegang teguh firman Tuhan. Dengan ketaatannya kepada firman Tuhan Nehemia dapat mengenal Allah lebih dalam. Nehemia selalu memegang janji Allah bahwa Allah akan memberlakukan perjanjian dan kasih setia-Nya terhadap orang kasih kepada-nya dan tetap mengikuti perintah-perintahNya (1:5). Nehemia juga mengutip apa yang telah difirmankan Allah, "Ingatlah akan firman yang Kau pesan kepada Musa, hamba-Mu itu....”(1:8,9).

John white menjelaskan,

"Pikiran Nehemia sudah penuh dengan Musa, dan permohonanya dalam ayat 8 dan 9 mencerminkan hal ini. Isi ayat-ayat ini diambilnya dari Ulangan 28:64 dan 30:1-4. Nehemia mengutip apa yang telah difirmankan Allah, "Bila kamu berubah setia, kamu akan kucerai beraikan di antara bangsa-bangsa. Tetapi, bila kamu berbalik pada-Ku dan tetap mengikuti perintah-perintah-Kuserta melakukannya, maka sekalipun orang buanganmu ada di ujung langit, akan Kukumpulkan mereka kembali dan Kubawa ke tempat yang telah Kupilih untuk membuat nama-Ku diam di sana." ${ }^{17}$

Iman Nehemia didasarkan atas pengetahuannya mengenai seperti apakah Allah sebenarnya. John White memberikan penjelasan bahwa "Nehemia setia pada Firman dan memegang teguh janji Allah. Nehemia melihat kedua sifat Allah. "Allah yang mahabesar dan dahsyat" sanggup melakukan sesuatu. Allah, "yang berpegang pada perjanjian dan kasih setiaNya", mau melakukan apapun juga. Nehemia tidak meragukan kekuasaan Allah maupun kemurahan-Nya"18

Pemahaman spiritualitas yang membawa transformasi pandangan tentang hal-hal yang dianggap paling bernilai dan patut dikerjakan selama hidupnya. Nilai-nilai tersebut dipengaruhi pemahaman tentang siapa dirinya dan tujuan hidupnya. Selain itu transformasi diri membawa perubahan ambisi (sasaran) hidupnya. Akar spiritual Nehemia memberikan kontribusi penting dalam keberhasilan kepemimpinannya antara lain mengenali kebutuhan nyata, sadar yang menjadi bagian Tuhan dan menjadi bagiannya sendiri.

Keintimannya dengan Tuhan sangat menolong Nehemia dalam menjalankan roda kepemimpinannya. Dengan kebiasaan berdoa dan taat pada kebenaran firman Tuhan ada 
kekuatan yang ia rasakan sehingga ia menjadi pribadi yang kuat dan tangguh. Inilah modal yang paling utama yang dimiliki oleh Nehemia yang membawa dia menjadi seorang pemimpin yang membawa sebuah perubahan ke arah yang lebih baik.

\section{Memiliki Visi yang Jelas}

Seseorang dikatakan berbahagia jika ia menemukan visi tersebut sebagai respon terhadap panggilan Allah. Dengan visi tersebut menjadikan hidup lebih efektif, adalah sebuah kesalahan fatal jika seorang pemimpin tidak menemukan visi dalam hiidupnya. Nehemia adalah seorang pemimpin yan memilki visi yang jelas dalam hidupnya.

Sebelum lebih jauh membahas bagaimana Nehemia menggumuli visi yang diberikan Tuhan serta bagai mana merealisasikan visi tersebut, terlebih dahulu penulis ingin memaparkan apa sebenarnya visi itu.

Menurut kamus bahasa Indonesia visi merupakan (1) daya lihat atau penglihatan; (2) pandangan terhadap suatu masalah. ${ }^{19}$

George Barna, yang dikutip oleh Sendjaya, mendefinisikan visi sebagai berikut, "visi adalah sebuah gambaran masa depan yang sangat jelas yang Allah komunikasikan kepada para pemimpin-pelayanan-Nya berdasarkan pengenalan yang akurat tentang Allah, diri sendiri, dan lingkungan."

Dari definisi di atas, visi adalah sebuah fusi atau perpaduan yang harmonis dari tiga elemen yang interpenden, yaitu: (1) Allah: Kehendak dan beban dari Allah, (2) Diri kita: talenta dan kapasitas yang Allah berikan, dan (3) Lingkungan: kebutuhan zaman yang Allah butuhkan. ${ }^{20}$

Dalam kitab Nehemia pasal satu dipaparkan bahwa Nehemia mendapat visi dari Allah. Visi itu lahir dari sebuah pergumulan yang dalam dan sesuai dengan kebutuhan, di mana kondisi kota Yerusalem ada dalam dan kehancuran serta temboknya tinggal berupa puing-puing. Ketika Nehemia mendengar hal tersebut, ia menjadi sedih dan berkabung beberapa hari (Neh. 1:4). Karena itu, ia mulai menaikan doa syafaat dan memohon kepada Allah supaya Allah turun tangan menolong bangsa Israel dan kota Yerusalem. Karena doanya, sehingga Tuhan memberikan visi dalam hatinya.

Visi pribadi Nehemia ditetapkan persis dengan yang Tuhan inginkan. Hal ini dapat kita lihat di dalam Nehemia 2: 12a: “.....Aku beritahukan rencana yang akan kulakukan untuk Yerusalem, yang diberikan Allahku dalam hatiku. Dari ayat ini kita bisa melihat bahwa Tuhan menaruh di dalam hati Nehemia sebuah visi yang begitu jelas dan visi itulah yang dijadikan sebagai visi pribadinya sesuai dengan kebutuhan.

Permohonan doanya kepada Tuhan terfokus pada pemecahan masalah yang ada di hadapannya yaitu penderitaan umat Israel dan pembangunan kembali tembok Yerusalem. Visi Nehemia sebagai seorang pemimpin tampak dalam penglihatan dan pandangan yang jauh ke depan berkenaan dengan rencana dan tujuan yang ingin dicapainya.

Visi Nehemia adalah membangun kembali tembok Yerusalem, sehingga bangsa Yahudi tidak ditindas, dan nama Tuhan dimuliakan. Uniknya, visinya menembus dua batas, yaitu batas fisik (kesejahteraan, keamaan kota melalui pembangunan tembok), juga rohani (nama Tuhan yang dimuliakan).

\section{Memiliki Perencanaan dan Strategi yang Matang}

Perencanaan merupakan suatu proses pemikiran rasional dan penetapan secara tepat mengenai berbagai macam hal yang akan dikerjakan di masa mendatang, dalam usaha mencapai tujuan yang telah ditentukan. Perencanaan adalah seleksi dari berbagai alternatif untuk maksud tujuan, kebijakan, prosedur, program dan sebagainya. Maka masalah penting dalam perencanaan adalah pengambilan keputusan, yang merupakan titik tolak yang menentukan arah kegiatan ke maa depan. ${ }^{21}$ 
Berdasarkan pengertian di atas, dalam perencanaan terdapat unsur-unsur sebagai berikut: Pertama, pemikiran rasional mengenai dugaan, perkiraan atau perhitungan untuk masa mendatang. Kedua, pemikiran rasional itu tidak dibuat atas dasar khayalan belaka, tetapi berdasar pada fakta atau data yang objektif. Ketiga, persiapan atau tindakan pendahuluan untuk kegiatan masa yang akan datang. Keempat adalah tujuan. ${ }^{22}$

Nehemia adalah sosok pemimpin yang punya perencanaan. Pemimpin yang punya rencana tidak gegabah, dia memulai rencana dengan melibatkan Tuhan dan dengan menggunakan kuasa raja untuk memuluskan proses pembangunan tembok. Dia mulai mendoakannya, Nehemia l:1lb: ".....biarlah hambamu berhasil hari ini dan mendapat belas kasihan dari orang ini." Ketika itu aku ini juru minum raja."

Target awalnya ialah mendapat ijin raja kemudian ia meminta surat-surat kepada para gubernur di daerah-daerah yang dilalui olehnya dalam perjalanannya ke Yerusalem. Setelah itu, ia juga meminta surat-surat kepada para penjaga taman miliki raja-raja, agar dapat memperoleh kayu yang diperlukan untuk memasang balok-balok pada pintu gerbang di benteng dan untuk tembok kota (2:8). Saat ditanya berapa lama ia akan meninggalkan pekerjaannya, Nehemia bisa langsung menjawab suatu waktu tertentu, tentu ini disebabkan karena ia sudah memiliki perencanaan sebelumnya, Nehemia 2:6: "Lalu bertanyalah raja kepadaku, sedang permaisuri duduk di sampingnya: "Berapa lama engkau dalam perjalan, dan bilakah engkau kembali?" dan raja berkenan mengutus aku, sesudah aku menyebut jangka waktu kepadanya."

Setelah sampai di Yerusalem, Nehemia tidak berhenti untuk membuat rencana, ia sangat hati-hati dan tidak serta-merta melakukan pekerjaannya. Dalam pasal 2:ll dikatakan, "Maka tibalah aku di Yerusalem. ....tiga hari aku di sana." Baru setelah beberapa hari, setelah ia dengan cermat dapat menilai keadaan , barulah ia mulai bertindak. Nehemia 2:12a: "Bangunlah aku pada malam hari bersama-sama beberapa orang saja menyertai aku. Aku tidak beritahukan kepada siapapun rencana yang akan kulakukan untuk Yerusalem." Dia mengumpulkan data dan fakta untuk untuk menyusun rencana, karena dengan fakta dan data itu, Nehemia dengan cepat membagi tugas dan susunan tahapan pekerjaan yang dilakukan, dalam proyek pembangunan tersebut, karena ada perencanaan yang matang sebelumnya.

Tidak sampai di situ saja, pada waktu Nehemia mendengar bahwa ada sebagian orang berencana untuk menyerang Yerusalem agar terjadi kekacauan, Nehemia segera bertindak dan menyusun strategi yang baik. Ia bertindak dengan menggerakkan kekuatan rakyat. Nehemia membagi bawahannya menjadi dua kelompok, yaitu satu kelompok akan tetap bekerja menyelesaikan pembangunan tembok dan kelompok lain akan senantiasa berjaga-jaga untuk mengawasi keamanan Yerusalem, sampai tembok selesai di bangun. Ketika pembangunan tembok telah selesai, Nehemia mengangkat orang-orang yang dapat membantu dia untuk menjaga Yerusalem (Neh. 7:1-73). Inilah strategi jitu yang dijalankan Nehemia sehingga ia berhasil.

Dari uraian di atas, penulis melihat bahwa dalam menjalankan sebuah tugas dan tanggung jawab yang besar, Nehemia menyusun perencanaan dan strategi yang matang dengan melihat fakta yang ada di lapangan. Dia tidak gegabah, melainkan dengan hati-hati dan teliti. Di samping itu, di selalu melibatkan Tuhan dalam setiap perencanaannya.

\section{Memiliki Keberanian Dalam Menghadapi Tantangan}

Salah satu kenyataan yang dihadapi dalam sebuah kepemimpinan adalah bahwa setiap pemimpin akan menghadapi banyak tantangan. Tentu saja pernyataan ini akan memancing macam-macam reaksi untuk menentukan sikap dalam mengelola sebuah tantangan. Maju tidaknya seorang pemimpin, tergantung bagaimana ia memandang situasi yang ada, agar setiap tantangan yang datang dapat dihadapi dan dari tantangan itu menghasilkan perkara-perkara yang baru.

Memiliki pandangan yang positif terhadap tantangan yang ada akan memudahkan 
dua sisi yang berlawanan. Di satu sisi tantangan itu jika dapat dikelola dengan baik akan menghasilkan sejarah baru dalam kepemimpinannya. Di sisi lain, tantangan dapat membawa seseorang kepada ketidakmampuan, dan akhirnya frustasi.

Dr. P. Octavianus menjelaskan bahwa, "pememimpin yang sesungguhnya adalah pemimpin yang senantiasa melihat kesulitan atau tantangan sebagai suatu peluang untuk menemukan perkara yang baru dalam membuat suatu sejarah. Sedang pemimpin yang melihat tantangan sebagai suatu kesulitan ialah pemimpin yang pesimis." ${ }^{23}$

Dalam kepemimpinan Nehemia, penulis melihat bahwa Nehemia mengahadapi banyak tantangan, tantangan itu tiadak hanya datang dari dalam saja tetapi juga datang dari luar. Berikut ini penulis akan memaparkan berbagai tantangan yang dihadapi dan bagaimana ia menyikapinya.

Dalam pasal 2:9: "Ketika Sanbalat orang Haron dan Tobia orang Amon, pelayan itu, mendengar hal itu, mereka sangat kesal karena ada orang yang datang mengusahakan kesejahteraan orang Israel." Dari awal kedua orang ini merasa tidak senang akan kehadiran Nehemia. Kemudian dalam pasal 2:19 dijelaskan bahwa mereka (Sanbalat, Tobia dan Gesyem) mulai mengolok-olok dan menghina perencanaan yang dilakukan Nehemia. Akan tetapi, Nehemia tidak terpengaruh dengan perkataan mereka dan menjawab dengan bijak: "Allah semesta langit Dialah yang membuat kami berhasil! Kami, hamba-hamba-Nya, telah siap untuk membangun."

Tantangan itu berlanjut pada pasal 4 ketika Nehemia dan segenap rakyat mulai membangun tembok Yerusalem. Dalam ayat 1-6, Nehemia dan umatnya menghadapi cemohan, tetapi Nehemia menghadapinya dengan begitu luar biasa. Nehemia tidak terpancing emosi tetapi dia datang kepada Tuhan melalui doa. Cemohan yang datang diatasi dengan doa. Kemudian ayat 7-9, mereka mendapat ancaman perang dan kekacauan, namun Nehemia mengatasinya melalui doa dan keamanan diatur dengan bijaksana (ayat 9).

Selain tantangan diatas, Nehemia mengalami tantangan yang cukup berat, di mana orangorang yang bekerja mulai patah semangat dan mengalami ketakutan. Pasal 4:10 berbunyi, "Berkatalah orang Yehuda: "Kekuatan para pengangkat sudah merosot dan puing masih sangat banyak. Tak sanggup kami membangun tembok ini.” Ini merupakan tantangan yang cukup berat di mana orang Yehuda mulai patah semangat dan ketakutan dalam membangun tembok Yerusalem. Dalam kondisi demikian, Nehemia hadir sebagai sosok pemimpin yang luar biasa. Dia mengatasi dengan iman dan kesalehan, juga memberi dorongan dan kesiapan untuk melawan musuh melalui perencanaan yang matang (ayat 12-18).

Dalam pasal 6, penulis melihat adanya usaha intimidasi yang dilakukan oleh Tobia, Sanbalat dan Gesyem. Mereka berusaha untuk menghambat pembangunan Tembok Yerusalem dan berusaha mencelakakan Nehemia (ayat 2). Akan tetapi Nehemia tetap fokus pada pekerjaannya (ayat 3). Akan tetapi mereka terus berusaha untuk mengacaukan pembangunatembok erusalem dengan cara menyebarkan berita yang tidak benar tentang diri Nehemia (ayat 5-8), berusaha untuk membusukkan nama Nehemia dan mencela Nehemia (ayat 13). Dan yang lebih menyedihkan lagi, karena ada saudara-saudara palsu yang mengatakan berkerja bagi kehormatan Allah, tetapi sebenarnya bersekutu ddengan musuh Allah (ayat 14). Namun luar biasa tindakan atau respon Nehemia terhadap kejahatn mereka. Nehemia selalu berdoa dan mengandalkan Tuhan (ayat 14).

Tantangan yang dihadapi oleh Nehemia tidak hanya datang luar saja tetapi juga dari dalam. Dalam pasal 5, Nehemia sangat marah terhadap ketidakadilan ekonomi di antara orang Yahudi. Di mana golongan kaya, yaitu bangsawan dan pejabat (ayat 7), menindas kaum miskin dengan memaksa mereka menggadaikan tanah dan rumah mereka serta meminjam uang untuk membeli makanan. Dalam beberapa kasus, kaum miskin dipaksa untuk menyerahkan anak-anak mereka sebagai budak agar mereka tidak mati kelaparan (ayat 1-5). Denga marah Nehemia menentang ketidakadilan ini (ayat 6) dan memaksa para pelanggar untuk bertobat dan memperbaiki diri 
(ayat 12-13). Kemarahan Nehemia terhadap ketidakadilan dan kejahatan merupakan kemarahan yang saleh karena rasa kepeduliannya terhadap orang miskin yang tertindas.

Dari uraian di atas, penulis melihat bahwa sekalipun Nehemia menghadapi tantangan, dia tidak mudah digoyahkan, serta tidak mudah putus asa oleh situasi yang tidak menyenangkan. Ketika tembok Yerusalem selesai dalam 52 hari, musuh orang Yahudi pun harus mengakui bahwa pekerjaan itu dilakukan dengan bantuan Allah (Neh. 6:15-16). Rahasianya adalah dia selalu mengandalkan Tuhan dan percaya Allah pasti menolong. Nehemia menunjukkan keberanian, ketetapan hati dan iman ketika berhadapan dengan perlawanan musuh (Neh. 4:14). Nehemia begitu yakin bahwa ketika umat-Nya melaksanakan bagian mereka dengan iman yang tekun, Allah pasti melaksanakan apa yang menjadi bagian-Nya. Nehemia berkata: "Allah semesta langit, Dialah yang membuat kami berhasil." (2:20a).

\section{Memiliki Integritas yang Tinggi}

Banyak orang yang sering memperbincangkan masalah integritas, namun tidak semua orang memiliki integritas. Kepemimpinan Kristen dicirikan melalui integritas, konsistensi, ketulusan, kejujuran, transparansi, keautentikan, dan keandalan, dan integritas menjadi ciri utama seorang pemimpin. kepemimpinan dalam komunitas membutuhkan kehidupan yang berintegritas.

Apa sebenarnya yang dimaksud dengan integritas itu? Dalam kitab Perjanjian Lama, Kejadian 20:1-6, kata integritas berasal dari kata "tom" yang berarti "keseluruhan/lengkap."24 Sedangkan dalam kitab Perjanjian Baru, rasul Yakobus mendefinisikan integritas sebagai sempurna dan utuh dan tidak kekurangan satu apa pun" (Yakobus 1:4). Bahwa iman dan perbuatan adalah satu.

Dalam kamus Besar Bahasa Indonesia, integritas berarti: "mutu, sifat atau keadaan yang menunjukkan kesatuan yang utuh sehingga memiliki potensi dan kemampuan yang memancarkan kewibawaan, kejujuran". 25

Denis Waitley mengatakan:

Sinonim untuk integritas adalah kejujuran, sifat bisa dipercaya, kehormatan, dan sifat bermoral. Menanamkan ini dalan kesadaran dan hati nurani anda akan menempatkan anda jauh di depan orang-orang lainnya dalam jangka panjang sehingga anda akan keheranan mengapa setiap orang tidak melakukan hal yang sama. Dan kualitas ini tidak hanya diperlukan dalam keputusan besar. Integritas yang lengkap dalam hal-hal kecil sama sekali bukan hal yang sepeleh". 26

Menurut Sendjaya, integritas merupakan konsistensi antara perkataan dan perbuatan kita, sama seperti istilah yang disebut WYSIWYG (what you see is what you get). Jika orang lain mendapati inkonsistensi dalam perkataan dan perbuatan kita, maka mereka akan melihat kita sebagai orang yang munafik." 27

Orang yang berintegritas akan selalu berusaha untuk menampilkan keselarasan antara perkataan dan perbuatan, kapanpun dan di manapun dia berada.

Nehemia adalah seorang pemimpin yang memiliki integritas yang tinggi. Ia sangat menjujung tinggi arti sebuah integritas dalam hidupnya. Hal ini sangat nampak dalam kehidupannya, dia adalah pemimpin yang dapat dipercaya. Karena integritasnya, sehingga ia menjadi pribadi yang dipercaya oleh banyak orang. Ada beberapa bukti bahwa dia adalah seorang yang memiliki integritas yang tinggi dan dapat dipercaya. Dengan posisinya sebagai juru minum raja, sudah membuktikan bahwa dia adalah orang yang dapat dipercaya. Alasannya karena juru minum raja bersentuhan langsung dengan raja, selain itu juga banyak pembicaraan

${ }^{24}$ James Strong, The Exhaustive concordance of the Bible. S.v. "Integrity". (lowa Falls, lowa: World Bible Publishers, n.d.). 
rahasia yang akan didengar juga karena dia adalah orang buangan, tentu raja-raja memilih orangorang yang terbaik, dalam hal ini dapat dipercaya.

Bukti lain bahwa dia adalah seorang yang memiliki integritas yang tinggi dan dapat dipercaya ialah saat Nehemia meminta ijin untuk tidak bekerja sementara waktu, Nehemia 2:6: "lalu bertanyalah raja kepadaku, sedang permaisuri duduk di sampingnya: "Berapa lama engkau dalam perjalanan, dan bilakah engkau kembali?" Dan raja berkenan mengutus aku, sesudah aku menyebut suatu jangka waktu kepadanya." Tampak jelas, raja dan permaisuri pada waktu itu, tidak mencurigai Nehemia untuk kabur dan tidak kembali lagi, atau memberontak kepada raja. Tetapi sesudah beberapa waktu aku minta izin dari raja untuk pergi." Dia dapat dipercaya, karena dia selalu menepati janji-janjinya. Selain itu saat dia meminta surat kuasa dan kayu untuk pembangunan tembok, selain bagian Tuhan yang membuat hati raja Artahsasta bermurah hati, juga ada bagian Nehemia yang dapat dipercaya.

Integritas Nehemia tercermin dari ketulusan hatinya dalam membangun tembok Yerusalem dan kepeduliannya yang tulus pada kesejahteraan orang lain sangat nyata sampai musuh-musuhnya pun melihatnya (2:10). Di samping itu, Nehemia juga tidak menggunakan kedudukannya untuk mengambil keuntungan bahkan memeras rakyat seperti yang dilakukan oleh pejabat-pejabat tinggi lainnya. Namun sebaliknya ia menentang akan ketidakadilan yang terjadi dalam masyarakat Yahudi. Ketika proses pembangunan sedang berlangsung, ia tidak hanya memberi perintah, tetapi ia juga terjun langsung dalam pembangunan tersebut.

Dari uraian di atas penulis menyimpulkan bahwa Nehemia merupakan sosok pemimpin yang memiliki integritas yang tinggi sehingga dapat dipercaya. Ia mampu mempertahankan integritasnya dalam situasi yang tidak memungkinkan sekalipun. Integritasnya yang tinggi membuat orang senang kepadanya dan Allah mempercayakan perkara yang luar biasa kepadanya.

\section{Memiliki Interpersonal Skill yang Baik}

Interpersonal skill merupakan salah satu ciri kepemimpinan Nehemia yang cukup menonjol. Hal ini Nampak dengan jelas dalam pasal 5:1-13; 7:1-3. Karena hal ini sangat penting, maka pemimpin harus dapat mengembangkannya.

John H. zenger yang dikutip oleh Daniel mengatakan, ada lima hal penting yang dapat dilakukan seorang pemimpin untuk mengembangkan "interpersonal skillnya" yang kuat, yaitu: ${ }^{28}$

Pertama, communicate powerfully and prolically. Yaitu pemimpin harus mengembangkan kepekaan orang-orang yang dipimpinnya terhadap arah dan tujuan yang ingin dicapai. Menolong banyak orang untuk mengerti bagaimana mereka memberi kepada kontribusi kepada tujuan organisasi. Kedua, Inspire others to high performance. Pemimpin besar menyemangati orang-orang untuk berjalan lebih jauh lagi. Menetapkan tujuan-tujuan yang lebih besar. Memotivasi orang-orang untuk mencapai lebih dari apa yang mereka pikirkan. Ketiga, Build trust pemimpin yang luar biasa bertindak sehingga pihak-pihak lain mempercayainya. Para pemimpin mempunyai keseimbangan perhatian mereka untuk produktivitas dan hasil dengan kepekaaan terhadap kepekaan kebutuhan dan masalah dari pegawai. Ketika koflik-konflik timbul, mereka akan bersentuhan dengan dengan perasaan para pegawai di samping aspek-aspek tekhnik dari masalah itu sendiri. Keempat, develop others. Suatu yang luar biasa dari seorang pemimpin adalah mendukung orang lain untuk memberikan umpan balik yang jujur dan membangun, berimbang antara antara koreksi dengan evaluasi positif. Mereka tetap hadir atas akan apa yang terjadi pada karier dan pegawai. Membiarkan orang lain berkembang, meskipun hal itu berarti akan membiarkan mereka meninggalkan departemen bagiannya. Kelima, collaborate and develop srong teams. Pemimpin yang luar biasa mengetahui bahwa mereka tidak mengisolasi diri mereka sendiri dari anggota tim yang lain. Mereka tetap berkomunikasi, sehingga kerjasama diutamakan dari pada berkompetisi. 
Pada penampilan diri dan kepemimpinan Nehemia, maka tampak beberpa karakteristik yang menggambarkan interpersonal skillnya, antara lain:

\section{Nehemia adalah Motivator yang Baik.}

Dalam kitab Nehemia, ada berbagai fakta yang menjelaskan bahwa Nehemia adalah motivator yang baik. Ia adalah pribadi yang senantiasa memberikan dorongan serta arahan yang tepat terhadap bawahannya, Nehemia berkata, "Mari, kita bangun kembali tembok Yerusalem, supaya kita tidak lagi dicela..." (Neh. 2:17b-18). Pemberian motivasi tersebut meningkatkan kualitas dan tingkat produktivitas kerja para bawahannya. Hal ini nampak pula dalam pasal 4:14, di mana orang Yehuda mulai putus asa dan merasa tidak berdaya, Nehemia hadir memberi motivasi, ia berkata, "Jangan kamu takut kepada mereka! ingatlah kepada Tuhan yang maha besar dan dahsyat....". Semangat dan dorongan yang diberikan kepada mereka akhirnya membuat mereka mulai bangkit kembali. J. Oswald Sanders mengemukakan pendapatnya tentang ayat di atas, yakni, "Ia membangkitkan semangat rekan-rekannya. Ini merupakan fungsi yang penting dari seorang pemimpin yang bertanggung jawab. Ia mencapai tujuan ini dengan memberikan dorongan iman dan memalingkan pikiran mereka dari besarnya masalah mereka kepada kepada kebesaran Allah dan sifat-Nya yang dapat dipercaya". ${ }^{29}$

Dari uraian diatas, dapat disimpulkan bahwa Nehemia adalah seorang motivator yang baik, takkala bawahannya sedang patah semangat dan tak berdaya, ia hadir sebagai pribadi yang sanggup membangkitkan semangat mereka.

\section{Nehemia adalah Komunikator yang Baik}

Komunikasi merupakan suatu proses penyampaian dan penerimaan berita atau informasi dari seseorang ke pada orang lain. ${ }^{30}$ Komunikasi merupakan fasilitas utama dalam kepemimpinan. Sebab tanpa komunikasi, maka fakta, gagasan dan pengalaman tidak dapat disalurkan baik secara vertikal maupun secara horizontal. Nehemia seorang pemimpin yang memiliki kemampuan yang sangat baik dalam hhal berkomunikasi.

Dalam Nehemia 2:17 "Berkatalah aku kepada mereka: "Kamu lihat kemalangan yang kita alami, yakni Yerusalem telah menjadi reruntuhan dan pintu-pintu gerbangnya telah terbakar....".

Dalam diri Nehemia sangat jelas kemampuannya dalam bergaul dan dalam berinteraksi dengan orang-orang yang dipimpinnya. Inilah keunggulan Nehemia dimana ia dapat berbuat lebih banyak dan sanggup mempengaruhi orang-orang yang dia pimpin.

\section{Memiliki Sikap Pemberdaya}

Salah satu kunci sukses bagi seorang pemimpin yang berhasil adalah menjadi seorang pemberdaya. Cara yang terbaik dalam memberdayakan orang lain adalah dengan cara mendelegasikan tugas sesuai dengan situasi, tempat dan kemampuan orang-orang yang dipimpin.

Delegasi adalah proses penyerahan tanggung jawab dan wewenang kepada orang lain. Dalam terang perjanjian lama, Tuhan memperlihatkan bagaiman pentingnya pendelegasian tugas itu. (Bil. 1l:10-15). Seni pendelegasia itu menyangkut orang-orang tepat dan pada waktu yang tepat pula.

Dr. P Octavianus menjelaskan bahwa, "Seorang pemimpin yang baik menyadari kesanggupan serta keterbatasan dan meyakini pula akan kesanggupan orang-orang yang akan dipimpinnya. Oleh karena itu ia harus belajar melepaskan tugas-tugas tertentu untuk dikerjakan orang-orang yang dipimpinnya. ${ }^{31}$

Adapun tujuan dari sikap pendelegasian yang positif yaitu,

Pertama, untuk mendapatkan orang-orang lain yang cakap melakukan tugas-tugas itu baik waktu darurat atau waktu-waktu yang akan datang. Kedua, dengan pendelegasian itu banyak banyak orang dilibatkan dalam tugas kepemimpinan, sehingga mencegah kegagalan yang mungkin timbul. Ketiga, dengan pendelegasian yang tepat, maka pekerjaan itu dapat banyak dan lebih baik. ${ }^{32}$ 
Pendelegasian tugas dapat dilihat ketika Nehemia mulai menggerakkan dan menempatkan orang-orang yang dipimpinnya. Ini Nampak secara jelas ketika ketika dia memberdayakan para pemimpin-pemimpin lain seperti Bupati di seberang Efrat serta dorongan kepada orang-orang Israel untuk membangun reruntuhan tembok Yerusalem (Neh. 2,3). Ketika tembok selesai dibangun, Nehemia mengangkat para penjaga pintu, para penyanyi, dan orang-orang Lewi diperintahkannya untuk melakukan tugasnya masing-masing. Di samping itu, pengawasan kota Yerusalem diserahkan kepada Hanani sehingga dengan demikian semua pekerjaan dapat berjalan dengan baik (Neh. 7:1-73).

Dari uraian di atas sudah Nampak jelas bagaimana bisa dan mau mempercayai orang-orang bawahannya serta mendelegasikan tanggung jawab kepada bawahannya sesuai dengankemampuan masing-masing. Alasannya sangat jelas. Pertama, sebagai manusia terbatas, Nehemia tidak mungkin melakukan perkara yang besar dengan mengandalkan kekuatannya sendiri. Kedua, Nehemia melihat potensi yang begitu besar dalam diri orang-orang yang dipimpinnya, sehingga ia mau memberdayakan potensi yang ada. Ketiga, Nehemia ingin melihat orang-orang yang dipimpinnya belajar untuk menjadi seorang pemimpin.

Ketujuh prinsip di atas membawa Nehemia menjadi seorang pemimpin yang membawa sebuah perubahan yang luar biasa. Di bidang fisik, ia mampu membangun tembok Yerusalem dalam tempo yang sangat singkat yakni 52 hari (Neh.6:15). Di bidang rohani, ia mampu mengadakan kebangunan rohani secara besar-besaran. Pasal 8-10 menguraikan dengan jelas prinsip mendasar bagi pembaharuan dan kebangunan rohani. Pertama, pembaharuan dan kebangunan rohani datang dari Allah melalui penyampaian firman Tuhan (8:1-8), doa (8:1), pengakuan dosa (pasal 9), berbalik dari hidup yang berdosa dan perilaku masyarakat kontemporer (9:2), dan penyerahann yang diperbaharui untuk melaksanakan kehendak Allah dan menjadikan firman Allah pedoman hidup yang penuh rasa syukur (10:29). Inilah prestasi yang luar biasa yang telah dicapai oleh Nehemia.

\section{Implikasi Kepemimpinan Nehemia Bagi Kepemimpinan Rohani Masa kini}

\section{Aspek Spiritual}

Nehemia adalah seorang pemimpin yang tidak diragukan lagi dalam hal kerohanian. Ia tetap mempertahankan kualitas rohani sekalipun dia menghadapi banyak tantangan dan pergumulan hidup. Kualitas rohani tercermin lewat kehidupan doa, mentaati firman Tuhan dan mengandalkan kuasa Allah.

\section{Setia dalam Berdoa}

Doa merupakan pernyataan naluri keagamaan yang paling tua, paling universal dan paling kuat. Doa dapat menjangkau perkara-perkara yang paling dalam, karena doa merupakan cara yang paling sederhana untuk berkata-kata sehingga bibir seseorang anak dapat mencobanya, dan juga merupakan keluhan yang terdalam yang dapat mencapai Yang Mahamulia di sorga. Sungguh doa merupakan nafas dan udara asli yang sangat vital bagi orang Kristen. ${ }^{33}$

Melakukan perkerjaan yang besar seperti yang dilakukan oleh Nehemia bukanlah pekerjaan yang mudah. Dan tantangan yang dihadapi dalam masa kepemimpinannya bukanlah suatu hal yang gampang untuk dihadapi. Ketika Nehemia menghadapi berbagai macam tantangan ia selalu membawa semua itu kepada Tuhan melalui doa. Di sni nampak bahwa Nehemia menyadari akan keterbatasannya sebagai manusia biasa. Oleh karena ketekunannya dalam hal berdoa sehingga Tuhan selalu memberi perlindungan dan kemenangan kepadanya.

Dalam kehidupan Nehemia, penulis melihat bahwa ia menyadari betul akan pentingnya doa itu. Di tengah kesibukan dalam melaksanakan tugas dan tanggung jawabnya, Nehemia selalu meluangkan waktu untuk berdoa kepada Tuhan. Inilah yang membawa dia kepada keberhasilan yang luar biasa. 
Menurut E.M. bounds bahwa doa merupakan tolak ukur suatu pelayanan yang berhasil. Hal ini didukung dengan pernyataannya sebagai berikut:

Setiap pelayanan yang benar-benar berhasil, doa adalah suatu kekuatan nyata yang mengontrol; nyata dan mengontrol perkara-perkara rohani yang mendalam di dalam pekerjaannya. Hasil-hasil yang dangkal dari setiap banyak pelayanan yang mati itu disebabkan karena kelalaian di dalam berdoa. Tidak ada pelayanan yang berlangsung terus tanpa banyak berdoa. ${ }^{34}$

Di era globalisasi ini, dalam menjalankan roda kepemimpinan tentu tidaklah mudah. Ada banyak tantangan dan godaan yang bisa saja menjatuhkan dan melumpuhkan para pemimpin. untuk itu, doa merupakan cara yang paling tepat untuk menolong para pemimpin dalam menjalankan roda kepemimpinan. Tanpa doa seorang pemimpin tidak mungkin mampu menghadapi berbagai macam tantangan. Peter Wongso berkata, "Doa adalah senjata peperangan rohani, bukan hiasan agama belaka." ${ }^{35}$ Semakin banyak berdoa, semakin banyak peluang untuk meraih keberhasilan.

\section{Taat Kepada Firman Tuhan}

Nehemia adalah seorang pemimpin yang taat pada firman Tuhan. Dan ia mendasari kepemimpinannya dengan firman Tuhan. Nehemia selalu mengutip firman Tuhan yang telah disampaikan oleh Musa $(1:$ 8,9) Hal ini juga nampak ketika pembangunan tembok Yerusalem selesai, Nehemia mengajak penduduk Yerusalem untuk mendengarkan firman yang dibacakan oleh Ezra. Nehemia tunduk pada otoritas firman Tuhan. Dia menjadi pelaku firman yang setia. Hal ini Nampak dalam perkataan dan perbuatannya. Firman Tuhan tidak hanya dia baca tetapi dia aplikasikan dalam kehidupannya.

Banyak pemimpin rohani yang mengalami kegagalan karena tidak mentaati firman Tuhan, tetapi lebih banyak mengikuti suara hati dan pikiran mereka sendiri. Kebanyakan dari mereka menjadi murtad dan munculya pengajar sesat atau nabi-nabi palsu yang memutarbalikkan kebenaran diganti dengan pandangan dan logika mereka sendiri ( Matius 7: 15-23; 24: 11, 24).

Pemimpin-pemimpin rohani masa kini haruslah mentaati firman Tuhan dan menjadikan firman Tuhan sebagai dasar utama dalam menjalankan kepemimpinannya. Pemimpin rohani haruslah memiliki prinsip "Back to The Bible" dan mendasari pelayanannya dengan firman Tuhandengan jalan meluangkan banyak waktu untuk meditasi, membaca, merenungkan dan mengaplikasikan firman Tuhan dalam setiap langkah kehidupan dan kepemimpinannya .

\section{Mengandalkan Kuasa Tuhan}

Nehemia menyadari akan kekurangan dan ketidakmampuan dalam dirinya dalam menjalankan kepemimpinannya. Oleh karena itu ia senantiasa mengandalkan kuasa Tuhan bukan mengandalkan kekuatannya sendiri. Takkala ia menghadapi tantangan dan musuhmusuhnya yang selalu saja ingin menjatuhkan dirinya, langkah awal yang diambil oleh Nehemia ialah datang dan berseru kepada Allah dan meminta petunjuk kepada-Nya. Sehingga Nehemia tidak salah dalam melangkah dan mengambil sebuah tindakan. Dengan mengandalkan kuasa Tuhan, ia mampu melakukan perkara yang luar biasa (membangun tembok Yerusalem) dan mampu mengalahkan musuh-musuhnya.

Pemimpin-pemimpin rohani masa kini perlu meneladani Nehemia dalam menjalankan kepemimpinannya yaitu menyerahkan seantero hidup dan kepemimpinannya dalam kuasa dan pimpinan Tuhan. Banyak pemimpin yang jatuh dalam berbagai macam dosa seperti dosa seks, uang, kedudukan, dan sebaginya karen mereka kesombongan mereka. Mereka mengandalkan kekuatan mereka tanpa mengandalkan kuasa dan pimpinan Tuhan. Tanpa kuasa dan pimpinan Tuhan seorang pemimpin tidak akan mungkin sukses dalam menjalankan roda kepemimpinan. 
Oleh karena itu, seorang pemimpin rohani perlu bersandar kepada kuasa dan pimpinan Tuhan dan selalu melibatkan Tuhan dalam seluruh aspek kehidupan maka maka ia akan memimipin setiap langkah dan kehidupan para pemimpin.

\section{Aspek Intelektual}

\section{Punya Wawasan Yang Luas}

Di era globalisasi ini pengetahuan menusia di berbagai bidang semakin meningkat dan berkembang dengan pesat. Sadar atau tidak sadar pemimpin-pemimpin rohani akan akan menghadapi dilema dalam kepemimpinannya, di mana mereka akan berhadapan orang-orang yang pintar, kritis dalam memberi komentar dan pertanyaan tentang berbagai hal yang menyangkut ilmu pengetahuan dan teknologi dalam hubungannya dengan firman Tuhan. Sebagai pemimpin rohani harus mampu menjawab pertanyaan dan menjawab kebutuhan mereka.

Untuk mengantisipasi pernyataan di atas, maka sebagai pemimpin rohani yang ingin berhasil dan membawa sebuah perubahan, haruslah memiliki pengetahuan yang luas. Pemimpinpemimpin rohani bukan hanya memiliki pengetahuan tentang Alkitab saja tetapi juga harus memiliki pengetahuan umum yang dapat ditempuh banyak membaca buku, melalui media massa, melalui media elektronik, internet, dan sebagainya untuk mendapat informasi yang lebih banyak lagi. Hal ini ditempuh dengan tujuan untuk dapat melayani atau memimpin orang-orang yang ada dalam jemaat yang memiliki tingkat pengatahuan, kepintaran dan keahlian dalam berbagai bidang, sehingga apa yang disampaikan baik melalui khotbah, nasehat, pengajaran dapat diterima oleh orang-orang yang dipimpin.

\section{Perencanaan yang Matang}

Nehemia adalah seorang pembentuk strategi dan perencanaan yang sangat baik. Ia mampu mengaplikasikan kebenaran. Dia tidak hanya menyadari tantangan-tantangan masa depan, tetapi dia juga mampu membentuk perencanaan untuk menghadapi semua tantangan itu. Dia menyadari kesempatan-kesempatan yang muncul dalam berbagai situasi dan dia mampu mencetuskan perenacanaan sesuai dengan kenyataan yang ada. Dengan perencanaan dan strateginya yang baik, menjadikan dia sebagai pemimpin yang tangguh dan sanggup mengadakan sebuah perubahan kearah yang lebih baik.

Pemimpin masa kini yang mampu membawa sebuah perubahan adalah pemimpin yang mampu melaksanakan semua rancangan dan pertimbangan dengan matang sehingga melahirkan strategi-strategi yang membawa kemenangan.

\section{Aspek Integritas}

Nehemia adalah pribadi yang menjunjung tinggi akan arti sebuah integritas dalam hidupnya. Ia melaksanakan tugas dan tangung jawabnya yang dipercayakan kepadanya dengan penuh kesetiaan, pengorbanan yang tulus, jujur dan rendah hati. Karena integritasnya, ia tidak hanya mendapat kepercayaan yang luar biasa dari raja Persia, tetapi orang-orang yang dia pimpin mempercayai dia sepenuhnya dan turut kepada Nehemia.

Nehemia adalah sosok pemimpin yang tidak hanya pandai untuk berkata-kata tetapi dia juga membuktikan lewat tindakan, sehingga banyak orang yang percaya kepadanya. Menurut John C. Maxwell, 
"Melalui integritas, seorang pemimpin akan dapat: membangun kepercayaan kepada pengikutnya, memiliki nilai pengaruh yang tinggi, memberikan standar-standar yang tinggi, memiliki tujuan sebelum memimpin orang lain, membantu seorang pemimpin menjadi kredibe, bukan hanya pandai saja serta dapat memenangkan sesuatu yang sulit melalui pertarungan yang tepat". ${ }^{36}$

Integritas merupakan hal yang sangat penting dalam menjalankan roda kepemimpinandan tanpa integritas tidak ada harapan bagi terwujuudnya kehidupan yang langgeng. ${ }^{37}$ Kepemimpinan rohani masa kini haruslah memiliki integritas yang tinggi. Sebab tanpa integritas, pemimpin tidak akan mampu mencapai keberhasilan dalam kepemimpinannya.

\section{Aspek Sosial}

Dalam menjalankan roda kepemimpinan, tentu saja seorang pemimpin tidak dapat dipisahkan dari orang-orang yang dipimpinnya. Dalam hal ini seorang pemimpin harus peka terhadap orang-orang di sekitarnya, memperhatikan kebutuhan mereka, senantiasa memberi semangat dan dorongan kepada mereka. sehingga orang-orang yang dipimpin juga merasa senang dan merasa bagian dari kehidupan pemimpinnya.

Nehemia ada contoh pemimpin yang memiliki nilai sosial yang sangat tinggi. Takkala rakyat sedang mengalami penindasan oleh para pemimpin mereka sendiri, Nehemia tampil sebagai pemimpin yang mau mendengar keluh kesah mereka. Nehemia mempu memimpin dengan baik karena ia selalu memberi dorongan dan semangat.

Tidak hanya itu, Nehemia adalah seorang pemimpin yang sanggup memberdayakan setiap potensi yang dimilikinya juga setiap potensi yang dimiliki oleh orang-orang yang dipimpinnya. Kemampuannya dalam memberdayakan potensi yang ada membawa dia menjadi seorang pemimpin yang sukses membuat sebuah perubahan. Semua potensi yang ada berhasil dia manfaatkan dengan sebaik mungkin mungkin sehingga tujuan bersama dapat tercapai. Jeff Hammond berkata, "Seorang pemimpin yang sukses akan mengelola sumber daya, staf, jemaat, keuangan, strategi dan visinya". ${ }^{38}$ Inilah yang nyata dalam kehidupan Nehemia.

Masalah kepemimpinan yang terjadi saat ini ialah sulitnya menjalin hubungan terhadap rekan-rekan sepelayanan. Dr. Daniel Ronda menjelaskan bahwa "masalah terbesar yang dihadapi beberapa pemimpin Kristen adalah memiliki minat yang rendah terhadap orang-orang serta tidak memiliki kemampuan menjalin hubungan rekan-rekan (interpersonal relationship), dan tidak peduli pada masalah-masalah emosional orang yang dipimpinnya." 39

Pemimpin masa kini yang sukses adalah dia yang mampu menjalin hungan antar rekan rekannya, member motivasi serta mampu mengkoordinir setiap potensi atau sumber daya yang ada. Kesuksesannya tergantung pada kemampuannya dalam melatih, melengkapi mereka dengan persenjataan dan mempersiapkan semua bawahannya agar melakukan strategi yang direncanakan. Sehingga perubahan ke arah yang lebih baik dapat terwujud dan dirasakan bersama-sama.

\footnotetext{
${ }^{36}$ John C. Maxwell, Mengembangkan Kepemimpinan di Sekitar Anda (Mitra Media: Edisi Khusus, 2001),
} 


\section{PENUTUP}

Setelah menyelesaikan seluruh uraian dalam bab-bab terdahulu maka pada bagian akhir dari tulisan ini, penulis akan memberikan pokok pikiran inti sebagai kesimpulan dan saransaran.

\section{Kesimpulan}

Kepemimpinan adalah suatu proses atau cara yang dilakukan oleh seorang pemimpin dalam mempengaruhi, mengajak, mendorong dan melibatkan orang lain (bekerja sama), serta memberdayakan potensi yang dimiliki orang lain dalam pencapaian tujuan bersama. Kepemimpinan merupakan hal yang sangat penting dan diperlukan dalam hal berkelompok aik secara formal, non formal, dan informal untuk mencapai suatu keteraturan dan keharmonisan dalam menetapkan dan mencapai tujuan bersama.

Sejak zaman perjanjian Lama dan Perjanjian Baru Alkitab telah menunjukkan bahwa kepemimpinan sudah diterapkan sejak dahulu. Sebagai contoh Nehemia, di mana Nehemia tampil sebagai pemimpin transformati yang sanggup membawa sebuah perubahan ke arah yang lebih baik. Di mana tembok Yerusalem berhasil dia bangun dalam tempo yang singkat ( 52 hari) juga ada kebangunan rohani yang terjadi dalam kehidupan rakyat di Yerusalem oleh karena campur tangan Allah dalam kehidupannya.

Dalam kepemimpinannya, Nehemia menghadapi banyak tantangan, godaan, dan permasalahan-permasalahan baik dari dalam maupun dari luar. Namun semua itu dapat dilalui dan diatasi oleh Nehemia oleh karena ia mengandalkan Tuhan. Selain dari pada itu, ada beberapa prinsip yang luar biasa yang melekat pada diri Nehemia sehinggan berhasil membuat sebuah perubahan besar baik secara fisik maupun secara rohani. Dalam menjalankan kepemipinannya.yaitu Nehemia memiliki hubungan yang intim dengan Tuhan, memiliki visi yang jelas, memiliki strategi dan perencanaan yang baik, memiliki keberanian dalam menghadapi tantangan, memiliki integritas yang tinggi, memiliki interpersonal skill yang baik, memiliki sikap pemberdaya.

Hal kepemimpinan Nehemia patut menjadi pedoman bagi pemimpin-pemimpin masa kini. Prinsip-prinsip kepemimpinan Nehemia dapat diimplikasikan oleh pemimpin-pemimpin rihani pada masa kini untuk membawa sebuah perubahan ke arah yang lebih baik melalui beberapa aspek yaitu aspek spiritual : setia berdoa, taat pada firman Tuhan dan mengandalkan kuasa Allah; aspek intelektual mempunyai wawasan yang luas dan punya perencanaan yang baik; aspek integritas, dan aspek sosial.

Inilah rahasia kekayaan dalam kepemimpinan Nehemia sebagai pemimpin transformatif. Ia berhasil mengadakan perubahan secara fisik dengan menyelesaikan pembangunan tembok Yerusalem. Dalam hal rohani ia mampu mengadakan kebangunan rohani. Suatu prestasi yang luar biasa.

\section{Saran}

Untuk mencapai suatu keberhasilan di dalam kepemimpinan rohani yang mampu membawa perubahan ke arah yang lebih baik maka pemimpin-pemimpin rohani perlu memikirkan dan melaksanakan beberepa hal yaitu:

Pertama, Pemimpin-pemimpin rohani pada masa kini seharusnya menjadikan prinsipprinsip kepemimpinan Nehemia sebagai pedoman dalam menjalankan roda kepemimpinan.

Kedua, Pemimpin-pemimpin rohani pada masa kini harus perlu melihat dan memberdayakan setiap potensi yang ada dalam jemaat untuk bersama-sama menjalankan visi dan misi yang ada.

Ketiga, Mengingat perkembangan ilmu pengetahuan dan teknologi semakin meningkat serta pengetahuan kaum awam semakin tinggi, maka para pemimpin hendaknya memiliki wawasan yang lebih luas. 
Kelima, Pemimpin-pemimpin masa kini hendaknya lebih mempertajam visi dan perlu meluangkan watu untuk lebih banyak berdoa.

Keenam, Pola kepemimpinan Nehemia juga cocok untuk diterapkan dalam kepemimpinan sekuler.

\section{KEPUSTAKAAN}

\section{Alkitab}

Barker Kenneth, Ed., The NIV Study Bible. New International Version Grand Rapids, Michigan: Zondervan Publishing House, 1985.

Lembaga Alkitab Indonesia, Alkitab:Perjanjian Lama dan Perjanjian Baru dalam Terjemahan Baru. Edisi Kedua, cetakan keempat, 1996.

Stamps, Donald C., Ed., Alkitab:Penuntun Hidup Berkelimpahan. Jakarta: Lembaga Alkitab Indonesia dan Malang:Gandum Mas, 1993.

\section{Kamus, Ensiklopedia dan Konkordansi}

Ensiklopedia Alkitab Masa Kini.Jilid 2. Jakarta:Yayasan Komunikasi Bina Kasih/OMF, 1996.

Kamus Besar Bahasa Indonesia.Jakarta:Balai Pustaka, 1989.

Kamus Umum Bahasa Indonesia.Jakarta:Balai Pustaka, 1989.

Strong,James The Exhaustive concordance of the Bible. S.v. "Integrity". lowa Falls, lowa: World Bible Publishers, n.d.

Thayer, Joseph Henry, The New Thayer's Greek-English Lexion of The New Testament. Paebody, Massachusetts, Hendrikson Pub., 1981.

\section{Buku-Buku}

Bakker, Anton dan Achmad Charris Zubair, Metodelogi Penelitian Filsafat, Yogyakarta: Kanisius, 1990.

Bounds, E.M. Kuasa Karena Doa. Surabaya: Yakin, n.d

Bowlig, John C. Kepemimpinan Penuh Kasih Karunia. Jakarta: Metanoia, 2001.

Hamond,Jeff .Kepemimpinan Yang Sukses. Jakarta: Metanoia 2003.

Maxwell,John C. Mengembangkan Kepemimpinan di Sekitar Anda . Mitra Media: Edisi Khusus, 2001.

Octavianus, P. Manajemen dan Kepemimpinan Menurut Wahyu Allah. Malang: Gamdum Mas, 2004.

Ronda, Daniel. Kepemimpinan Model Gembala. Bandung: Kalam Hidup,n.d.

Senduk,H.L. Kuasa Doa, Yayasan Bethel, 1985.

Sendjaya, Kepemimpinan Kristen: Konsep, Karakter dan Kompetensi. Yogyakarta: Kairos Books, 2004.

Sanders,Oswald. Kepemimpinan Rohani, Bandung: Kalam Hidup, 1987.Waitley,Denis. Kerajaan

Pikiran: Pelajaran untuk memimpin dan berhasil di dunia yang berdasarkan pengetahuan. Jakarta: Binarupa Aksara, 1996.

Thoha,Miftah .Perilaku Organisasi, Jakarta: CV Rajawaali, 1988.

White, John. Kepemimpinan Yang Handal, Bandung: Yayasan Kalam Hidup, 1994.

Wursanto, Pokok-pokok Perencanaan. Yogyakarta: Kanisius, 1987.

Wongso, Peter. Theologia penggembalaan. Malang: SAAT, 1983. 


\section{Bahan Kuliah, Makalah, dan Jurnal}

Djadi, Jermia, Diktat Teologi Pastoral. Makassar:STTJ Jaffray, 2000.

Ronda, Daniel, Kepemimpinan Model Gembala. Bandung:Kalam Hidup.

Tandirerung, Gideon, “Kepemimpinan”, Bahan Seminar Kepemimpinan.

Parapak, Jonathan. Kepemimpinan Kristen di Era IPTEK dan Globalisasi9 Materi Seminar Sehari Kepemimpinan Kristen.

Herlambang PS, Krisis Kepemimpinan? Model Pemimpin-Pelayan, Buletin Mitra,4.

\section{Bahan Internet}

Daniel, Kepemimpinan Transformatif. Diakses tanggal 20 maret 2010. Tersedia di http://danielmms.wordpress.com,2008.

Stamboel,Kemal. Masalah Pemimpin dan Kepemimpinan Baru di Indonesia. Diakses tanggal 15 Maret 2010. Tersedia di http://www.kemalstamboel.com/blog-manajemen/masalahpemimpin-dan-kepemimpinan-baru-indonesia.html

Sendjaya, "Memimpin Dengan Integritas," lead.sabda.org, diakses tanggal 22 April 2010; tersedia di http://www.lead.sabda.org/_pdf/pemimpin_dengan_integritas.pdf.

Wiki, Kepemimpinan. Diakses tanggal 18 April 2010. Tersedia di http://id.wikipedia.org.wiki/Kepemimpinan. 